穂数步合の堌加率は低下せず，収穫期迄堌加することが 察知される。

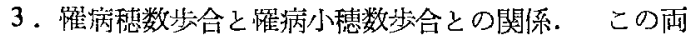
者の関係について調查持期別，憔病程度別にみると，苗 区の菊 3.国調查徖を除いて，いら゙れ子有意な正の相関が

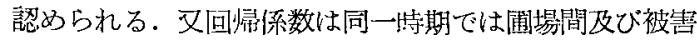

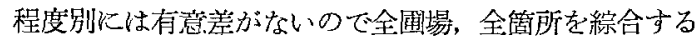
そ高い相関々係を示し，回臣係数は収稑期に近い程高く なり，各調查特期間には有意差が認められる。

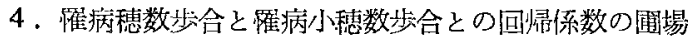
間，恃期間の茬異について。

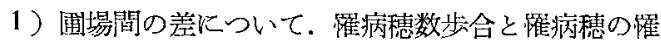
㨅小穂数步合との間には，正の相関が認められる. 往つ

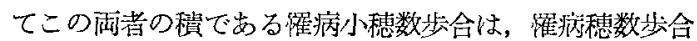
の増加に伴つて，明線的に堌加するものと考えられ，䍜

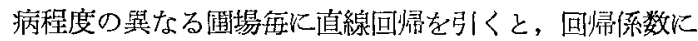

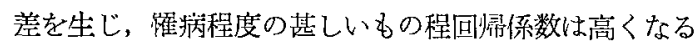
るのと考完られる。

2) 特期間の差について，第 1 図を見ると侍期が進む

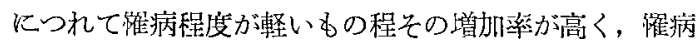
小穗数歩合の堌加は初期の篗病程度が軽い, 为の程低い.

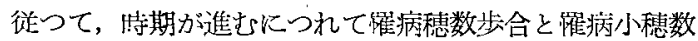
步合との国帰係数は大きくなるものと考えられる。

5. 損伤程度と収量構成要素及び減収步合との関係.

1) 小穂当着粒数. 損傷程度との間に相関が認められ ない.

第 2 表 收量誠查: 成 績

\begin{tabular}{|c|c|c|c|c|c|c|c|c|}
\hline 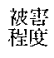 & 闌境 & 全料数 & 上唛重 & $\begin{array}{l}\text { 一小䅵当 } \\
\text { 薯粈数 }\end{array}$ & 支泣 & 积数翡合 & 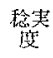 & $\begin{array}{l}\text { 減收 } \\
\text { 留合 }\end{array}$ \\
\hline 甚 & $\begin{array}{l}\text { I } \\
\text { II } \\
\text { III }\end{array}$ & $\begin{array}{r}\text { 粮 } \\
21,904 \\
18,828 \\
20,461\end{array}$ & $\begin{array}{r}\text { gr } \\
\mathbf{3 3 3} \\
358 \\
365\end{array}$ & $\begin{array}{r}\text { 粒 } \\
2.16 \\
2.20 \\
1.96\end{array}$ & $\begin{array}{c}\text { gr } \\
28.9 \\
30.4 \\
29.2\end{array}$ & $\begin{array}{l}52.7 \\
62.6 \\
61.2\end{array}$ & $\begin{array}{l}15.2 \\
19.0 \\
17.9\end{array}$ & $\begin{array}{c}\% \\
34.20 \\
17.75 \\
22.51\end{array}$ \\
\hline 中 & $\begin{array}{l}\text { IV } \\
\text { V } \\
\text { VI }\end{array}$ & $\begin{array}{l}22,487 \\
17,211 \\
18,996\end{array}$ & $\begin{array}{l}385 \\
303 \\
299\end{array}$ & $\begin{array}{l}2.07 \\
2.34 \\
2.44\end{array}$ & $\begin{array}{l}28.4 \\
27.8 \\
27.6\end{array}$ & $\begin{array}{l}60.2 \\
63.4 \\
56.9\end{array}$ & $\begin{array}{l}17 \\
17 \\
15\end{array}$ & $\begin{array}{l}23.32 \\
21.08 \\
29.60\end{array}$ \\
\hline 虹 & $\begin{array}{l}\text { VII } \\
\text { VII } \\
\text { IX }\end{array}$ & $\begin{array}{l}14,939 \\
23,342 \\
24,399\end{array}$ & $\begin{array}{l}266 \\
431 \\
442\end{array}$ & $\begin{array}{l}2.46 \\
2.27 \\
2.43\end{array}$ & $\begin{array}{l}26.9 \\
26.9 \\
27.1\end{array}$ & $\begin{array}{l}66.2 \\
68.6 \\
67.0\end{array}$ & $\begin{array}{l}17.8 \\
18.5 \\
18.2\end{array}$ & $\begin{array}{l}17.21 \\
13.95 \\
15.35\end{array}$ \\
\hline
\end{tabular}

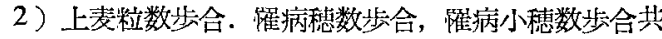
に高い相関々係を示し,.赤かび病被㕵による上麦粒数娍 少の影著なことを示している:

3）上麦子粒需. 損傷程度と上㘫千粒重との間には正

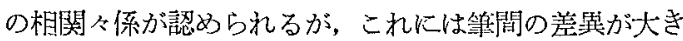
く影響していると考えられる点が多く，過去の成續によ ると正集闭方の成續を示しこの関係は明膫でない。

4 ）減収步合，損倁程度との間に有意な相関々係を示 し，成熟期が近づくにつれて，篗病穂数步合と減收步合

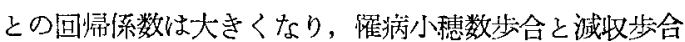
との回栕係数は小さくなる。このよ5に惟病程度と減収

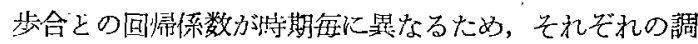
查弶期に応じた減収推定尺度を作成したものが第 3 表で ある。

第 3 表 減收推定尺度

\begin{tabular}{|c|c|c|c|c|c|c|c|c|c|}
\hline \multirow{3}{*}{ 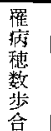 } & \multicolumn{3}{|c|}{ 州䄸 } & $20 \%$ & $30 \%$ & $40 \%$ & $50 \%$ & $60 \%$ & $70 \%$ \\
\hline & \multicolumn{3}{|c|}{ 出䄈期後 40 日㥧 } & 45 & 55 & 65 & 70 & 80 & 85 \\
\hline & 成 & 熟 & 期 & 60 & 65 & 70 & 75 & 85 & 90 \\
\hline 減 & $4 x$ & 歩 & 合 & 10 & 15 & 20 & 25 & 30 & 35 \\
\hline
\end{tabular}

\begin{tabular}{|c|c|c|c|c|c|c|c|c|c|}
\hline \multirow{3}{*}{$\begin{array}{l}\text { 䍜种 } \\
\text { 病数 } \\
\text { 小侴 }\end{array}$} & \multicolumn{3}{|c|}{ 出嘈期後 30 日㥧 } & $1 \%$ & $3 \%$ & $5, p^{\prime}$ & $7 \%$ & $9 \%$ & $11 \%$ \\
\hline & \multicolumn{3}{|c|}{ 出硙期後 40 日步 } & 5 & 8 & 10 & 12 & 14 & 16 \\
\hline & 成 & 然 & 期 & 8 & 10 & 15 & 17 & 20 & 23 \\
\hline
\end{tabular}

尺变使用上心注意

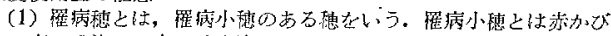

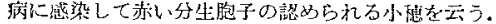

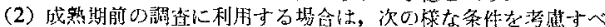

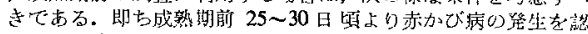

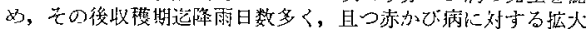
抵抗性の踤い品種に適用出来る。

参考文 献

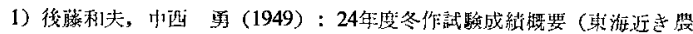

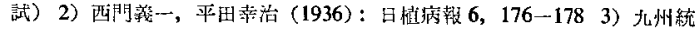

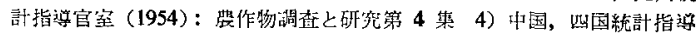

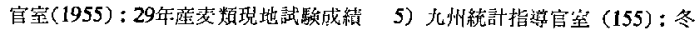
作現地硁駼成儤

13. 菜種菌核病抵抗性の検定に関寸る研究 第 1 報 國場に扣ける抵抗性の呾㮔間差異 滕川 隆 ・宇都宮 務・网留善次郎・中鶴政夫（大分罧農業試驗場）

1. 緒

言

著者等は 1953 年より, 本病 (病原菌 Sclerotinia sclerotiorum MASSEE) の抵抗性問題につき研究を繶行中でま るが,こ১では 1953〜1955 年の3ケ年にわたり, 樋場 に拈ける抵抗性の品種間差異につき奏験を行い，若干の 成績を得たのでその結果の概要を報告する.本研究を行

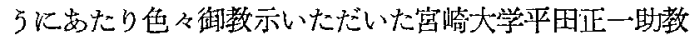

授，大分票試鹤田快夫場長並びに，田中收前場長に対し 感謝の意を表する。

\section{2. 実験方法並びに結果}

1953 年（第 1 年目）実験 $1 \ldots 1953$ 年 9 月 16 日播種し 肥料は坪当り，基肥として堆肥 1 蠳，硫安 30 多，過石 30 夾, 塩加 10 多を, 更他追肥として硫安 10 多を施し, 10 月 16 日に $5 \times 5$ 寸間隔に仮植を行い, 1 站当り基肥に堆 
肥 300 兾, 硫安 1.5 䨘, 過石 1.5 貫, 塩加 1.5 貫を, 尚追肥 として硫安 1.5 辐を施した。定植は畑栽培となし11月 25 日に行い，睢巾 3 尺，株間 1.2 尺，反当 3,000 本植と

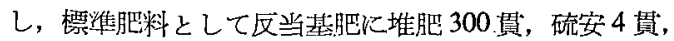

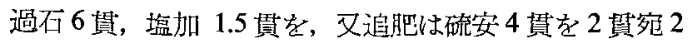
回に分抬し，1区 1.3 坪の 3 区制乱塊法とした。关の他 の管理は充分に行い，1954 年 5 月 18 日に各区全株（30 株)につき発病調查を行い, 被害指数(\%)を福岡農試查 定整淮により算出比較した結果は第 1 表のようである.

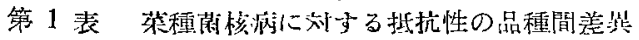
(1954. 5)

\begin{tabular}{|c|c|c|c|c|c|}
\hline \multirow{2}{*}{ 佚誠品棰 } & \multicolumn{4}{|c|}{ 被 害 指 数 (\%) } & \multirow{2}{*}{$\begin{array}{c}\text { 開花 } \text { 乩 }^{\text {(月日) }}\end{array}$} \\
\hline & I & II & III & 平均 & \\
\hline 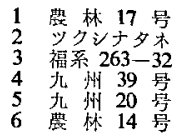 & $\begin{array}{r}30.7 \\
13.8 \\
42.0 \\
12.7 \\
8.0 \\
28.7\end{array}$ & $\begin{array}{r}25.3 \\
15.3 \\
37.3 \\
9.3 \\
6.0 \\
29.3\end{array}$ & $\begin{array}{r}38.0 \\
10.7 \\
24.7 \\
14.7 \\
2.7 \\
16.7\end{array}$ & $\begin{array}{r}31.3 \\
13.1 \\
34.7 \\
12.2 \\
5.6 \\
24.9\end{array}$ & $\begin{array}{l}2.26 \\
3.10 \\
2.12 \\
2.22 \\
2.28 \\
2.28\end{array}$ \\
\hline
\end{tabular}

第 1 表の成績を分散分析した結果，品種間に $1 \%$ 水䧱 にて有意性を認め, 発病の少い品種としては九州 20 号, 九州 39 号, ツクシナタ市等であり，農林 14 号, 農林 17 号, 福系 263-32 は比較的発病が多からた。

1954 年 (第 2 年目) 実験 1 1954 年 9 月 30 日播種, 無仮植育苗とし，施舥は坪当基肥として堆肥 1 貫，硫安 50 多, 過石 50 多, 塩加 17 㚈, 不灭 60 多を施し, 更に 硫安 30 多这追肥した。播種は $5 \times 5$ 寸の 3 粒播としその 後 2 回の閴引之中耕を行い, 11 月 16 日に甠巾 3 尺, 株 閒 1.2 尺，反当肥料の 5 割增 3,000 本植として烟汇定植 し，施肥は標淮とし，反当基肥淮肥 450 貴，硫安 6 貫，

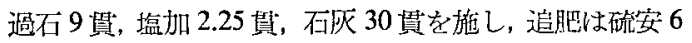
貫を 2 回に分湤した， 1 区 3 坪の 3 区制乱塊法となし， 前回同様乞の他の管理は充分に行い, 1955 年 5 月 19 日 に各区全株（30株）につき前年同様調査を行つた結果は 第2言のようである.

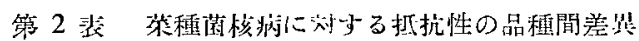
(1955. 5)

\begin{tabular}{|c|c|c|c|c|c|}
\hline \multirow{2}{*}{ 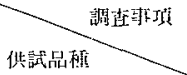 } & \multicolumn{4}{|c|}{ 波背 指 数 $(8)$} & \multirow{2}{*}{$\begin{array}{c}\text { 閒 北期 } \\
\text { (月白) }\end{array}$} \\
\hline & $\mathrm{T}$ & II & HIT & 北场 & \\
\hline 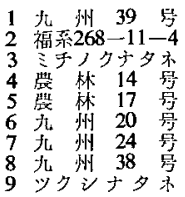 & $\begin{array}{r}15.3 \\
12.0 \\
52.0 \\
50.0 \\
48.0 \\
4.0 \\
18.7 \\
22.0 \\
33.3\end{array}$ & $\begin{array}{l}16.7 \\
11.3 \\
34.8 \\
44.0 \\
47.3 \\
14.7 \\
24.0 \\
36.7 \\
17.3\end{array}$ & $\begin{array}{l}14.0 \\
21.3 \\
29.3 \\
22.7 \\
50.7 \\
14.7 \\
18.0 \\
26.7 \\
43.3\end{array}$ & $\begin{array}{l}15.3 \\
14.9 \\
38.7 \\
38.9 \\
48.7 \\
11.1 \\
20.2 \\
28.5 \\
31.3\end{array}$ & $\begin{array}{l}3.1 \\
3.6 \\
2.24 \\
3.19 \\
3.13 \\
3.14 \\
3.28 \\
3.24 \\
3.22\end{array}$ \\
\hline
\end{tabular}

第 2 表の成績を分散分析した結果，1\%水淮にて有意 性を認め, 発满の少いものとしては九州 39 号, 福系 268 -11-4, 九州 20 号及び九州 24 号があり，九州 38 号, ックシナタネは中程度であり,さらに発病の多い品種と
してはミチノクナタネ, 農林 14 号, 農林 17 号等で女 つた.

実験 2、播種育苗は実験 1 と同様になし，11月・17日 に甠巾 5 尺, 株間 1.2 尺, 案間 2 尺の 2 条植とし, 反当 3,600 本を水田售作として植付けた，施肥は標淮肥料と して反当基肥泛堆肥 300 貴, 硫安 4 買, 過石 6 貫, 塩加 1.5 資, 不炚 20 貴を, 更に追肥として硫安 4 䐝を 2 回に 分施した， 1 区 3 坪，3区制乱塊法とし，その他の管理 を充分に行い, 1955 年 5 月 19 日に実験 1 同様発病調疽 を行つた結果は第了表のようである。

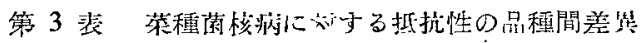

(1955. 5)

\begin{tabular}{|c|c|c|c|c|c|}
\hline \multirow{2}{*}{ 供試品種 } & \multicolumn{4}{|c|}{ 被 書 指 数 (\%) } & \multirow{2}{*}{$\begin{array}{l}\text { 開北期 } \\
\text { (月日) }\end{array}$} \\
\hline & I & II & IIII & 平均 & \\
\hline 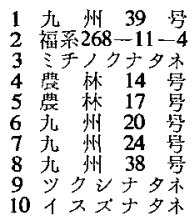 & $\begin{array}{l}2.0 \\
2.7 \\
6.0 \\
5.3 \\
7.3 \\
1.3 \\
2.0 \\
5.3 \\
3.3 \\
1.3\end{array}$ & $\begin{array}{r}5.3 \\
2.0 \\
11.3 \\
6.0 \\
12.7 \\
2.0 \\
7.3 \\
8.7 \\
5.3 \\
4.0\end{array}$ & $\begin{array}{r}2.7 \\
5.3 \\
14.0 \\
11.3 \\
6.0 \\
2.7 \\
13.3 \\
9.3 \\
5.3 \\
3.3\end{array}$ & $\begin{array}{r}3.3 \\
3.3 \\
10.4 \\
7.5 \\
8.7 \\
2.0 \\
7.5 \\
7.8 \\
4.6 \\
2.9\end{array}$ & $\begin{array}{l}2.27 \\
2.28 \\
2.23 \\
3.15 \\
3.10 \\
3.5 \\
3.27 \\
3.22 \\
3.22 \\
3.6\end{array}$ \\
\hline
\end{tabular}

第 3 表の結果をみるに，1％水準にて有意性を示し， 九州 24 号及び九州 38 号の発病が若干多くなつている外 は，実験 1 と略々同様の佂向であつた。

実験 3.11 月 18 日水田禀作として定植し，その他は 実験 2 と全く同一の才法にて栽培を行い, 1 区 1 坪の 4 区制乱塊法とした。满原菌の接種は 1955 年 3 月 28 日に 行つた. 即ち 1953 年分離した菌を使用し蔴糖添加稻荣

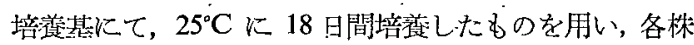

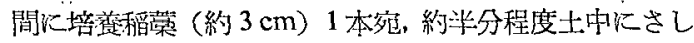
こみ間接接種した。そのご5月18日に各区全株 (12株) 調査した結果は第 4 表の上うである。

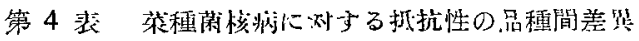
(19555. 5)

\begin{tabular}{|c|c|c|c|c|c|c|}
\hline \multirow{2}{*}{ 似試昆程 } & \multicolumn{5}{|c|}{ 被翟北 数 (96) } & \multirow{2}{*}{$\begin{array}{c}\text { 開 花期 } \\
\text { (月日) }\end{array}$} \\
\hline & $\mathrm{T}$ & II & III & IV & 平均 & \\
\hline 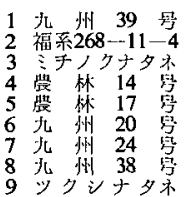 & $\begin{array}{r}10.0 \\
3.3 \\
8.3 \\
6.7 \\
23.3 \\
5.0 \\
8.3 \\
6.7 \\
1.7\end{array}$ & $\begin{array}{r}11.7 \\
1.7 \\
8.3 \\
3.3 \\
23.3 \\
3.3 \\
5.0 \\
8.3 \\
1.7\end{array}$ & $\begin{array}{r}13.3 \\
13.3 \\
11.7 \\
15.0 \\
15.0 \\
3.3 \\
21.7 \\
6.7 \\
8.3\end{array}$ & $\begin{array}{c}8.3 \\
0 \\
18.3 \\
10.0 \\
43.3 \\
0 \\
10.0 \\
16.7 \\
10.0\end{array}$ & $\begin{array}{r}10.8 \\
4.6 \\
11.7 \\
8.8 \\
26.2 \\
2.9 \\
11.3 \\
9.6 \\
5.4\end{array}$ & $\begin{array}{l}3.5 \\
3.7 \\
3.2 \\
3.14 \\
3.9 \\
3.8 \\
3.23 \\
3.22 \\
3.20\end{array}$ \\
\hline
\end{tabular}

第4 淁の結果をみるに品種閒にかなりの差がみられた が, 結局九州 39-号の発病が若一多くなつている外は, 実 験 2 と大差ない結果であつた。

実験 4 . 実驗 3 と全く同一の方法にて截培した無接種 区（1区 1 坪，2区制) について, 同じく 5 月 18 日調査 を行つた結果は第 5 表のようでめる。 


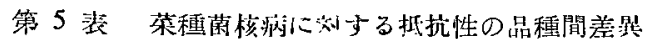
(1955. 5)

\begin{tabular}{|c|c|c|c|}
\hline \multirow{2}{*}{ 䛧試品赫 } & \multicolumn{3}{|c|}{ 被害 指 数 (96) } \\
\hline & $\mathrm{I}$ & II & 平均 \\
\hline 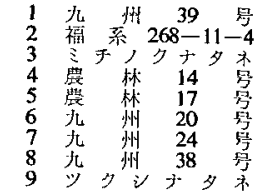 & $\begin{array}{r}0 \\
3.3 \\
6.7 \\
10.0 \\
20.0 \\
5.0 \\
8.3 \\
13.3 \\
10.0\end{array}$ & $\begin{array}{r}8.3 \\
1.7 \\
13.3 \\
11.7 \\
20.0 \\
5.0 \\
13.3 \\
1.7 \\
11.7\end{array}$ & $\begin{array}{r}4.2 \\
2.5 \\
10.0 \\
10.9 \\
20.0 \\
5.0 \\
10.8 \\
7.5 \\
10.9\end{array}$ \\
\hline
\end{tabular}

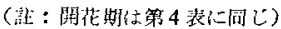

第 5 䘚の結果よりすれば，発病は若干少いが契験 3 と 略々同一傾问であつた。

1955 年（第 3 年目）实験 1 . 1955年 10 月 7 日播種 し，11月 22 日烟炡定植した，栽培管理乙の他は前年の 実験 1 K潗じて行い，1956年5月25日に各区全株 (30) につき発病調查を行つた結果は第6表のようでめる。

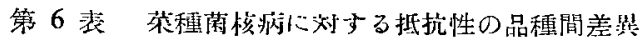

(1956. 5)

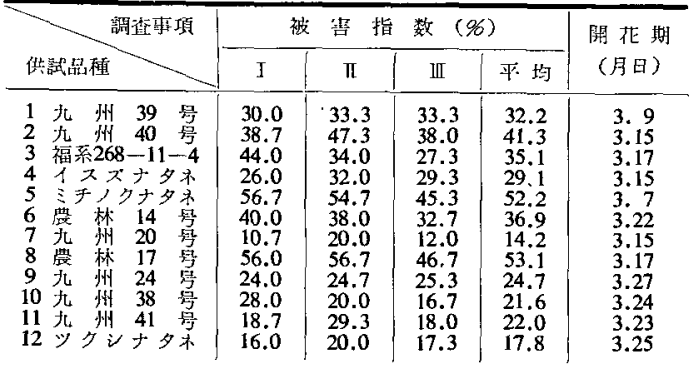

第 6 表の成績を分散分析した結果 $1 \%$ 水淮にて品種間 に有意性が証められ，発病の少小ものとしては九州 20 号，九州 38 号，九州 41 号，及びックシナタネ等があり， 農林 17 号, ミチノクナタネ及び九州 40 号は発病多く, その他の品種は多少変動はあるか，稍々中位の発病であ つた.

实験 2.10 月 7 日播種し，11月 22 日水田裏作として 定植した，その他は前年の実験 2 と全く同一方法にて実 験を行い，1956年 5 月 25 日に各区全株（30株）につき 発病調査を行つた結果は第 7 表の上万である.

第 7 表 荣種菌核病に対士可抵抗性の品種間差是

\begin{tabular}{|c|c|c|c|c|c|}
\hline 裯㮅 & & 兽 & 数 ( & & 開 花 期 \\
\hline 促試品種 & I & II & III & 平均 & (月吕) \\
\hline 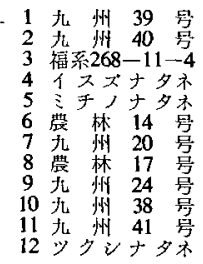 & $\begin{array}{r}9.3 \\
2.0 \\
4.7 \\
6.7 \\
10.7 \\
8.7 \\
6.7 \\
5.3 \\
1.3 \\
4.7 \\
9.3 \\
1.3\end{array}$ & $\begin{array}{r}7.3 \\
12.7 \\
2.7 \\
8.0 \\
12.0 \\
10.7 \\
7.3 \\
21.3 \\
2.7 \\
2.0 \\
5.3 \\
3.3\end{array}$ & $\begin{array}{r}6.0 \\
2.7 \\
8.0 \\
8.7 \\
21.3 \\
8.7 \\
8.7 \\
6.0 \\
4.0 \\
1.3 \\
2.0 \\
3.3\end{array}$ & $\begin{array}{r}7.5 \\
5.8 \\
5.1 \\
7.8 \\
14.7 \\
9.4 \\
7.6 \\
10.9 \\
2.7 \\
2.7 \\
5.5 \\
2.6\end{array}$ & $\begin{array}{l}3.10 \\
3.10 \\
3.14 \\
3.15 \\
3.44 \\
3.17 \\
3.16 \\
3.16 \\
3.27 \\
3.24 \\
3.24 \\
3.23\end{array}$ \\
\hline
\end{tabular}

第 7 表の結果をみるに，前年同様畑载培に比乙発病少 く, 若干の変動もみられたが，その傾向は実験Ｉと略々 同様であつた。

実驗 3.10月 7 日潘種し，11月 24 日水田聚作とし

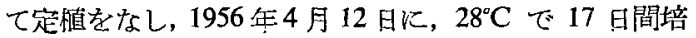
養した稻葆培羑菌 2 本宛を各株怎に，株際より約 3 寸の ところに接種した，その他は前年の寒駼 3 に淮じて管 理を充分に行い５月25日に各区全株（12株）につき調 查した結果は第 8 表のようである.

第 8 表 荣種菌核病に刘与万抵抗性の品種間差罷

(1956. 5)

\begin{tabular}{|c|c|c|c|c|c|c|}
\hline \multirow{2}{*}{ 供試品䅜 } & \multicolumn{5}{|c|}{ 被 繁 指 数 (9s) } & \multirow{2}{*}{$\begin{array}{c}\text { 闒任期 } \\
\text { (月日) }\end{array}$} \\
\hline & I & II & III & IV & 平坞 & \\
\hline 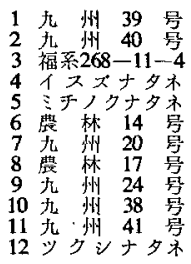 & $\begin{array}{r}11.7 \\
15.0 \\
10.0 \\
3.3 \\
30.0 \\
10.0 \\
5.0 \\
15.0 \\
13.3 \\
8.3 \\
13.3 \\
15.0\end{array}$ & $\begin{array}{r}15.0 \\
11.7 \\
18.3 \\
13.3 \\
15.0 \\
36.7 \\
5.0 \\
33.3 \\
11.7 \\
13.3 \\
11.7 \\
8.3\end{array}$ & $\begin{array}{r}11.7 \\
6.7 \\
15.0 \\
5.0 \\
62.7 \\
33.3 \\
11.7 \\
33.3 \\
11.7 \\
11.7 \\
23.3 \\
10.0\end{array}$ & $\begin{array}{r}15.0 \\
8.3 \\
25.0 \\
10.0 \\
6.7 \\
10.0 \\
5.0 \\
26.7 \\
11.7 \\
11.7 \\
10.0 \\
13.3\end{array}$ & $\begin{array}{r}13.4 \\
10.4 \\
17.1 \\
7.9 \\
19.6 \\
22.5 \\
6.7 \\
27.1 \\
12.1 \\
11.3 \\
14.6 \\
11.7\end{array}$ & $\begin{array}{l}3.12 \\
3.15 \\
3.16 \\
3.15 \\
3.8 \\
3.21 \\
3.19 \\
3.18 \\
3.23 \\
3.21 \\
3.23 \\
3.23\end{array}$ \\
\hline
\end{tabular}

第 8 表の結果を案ずるに, 前試験同様品種間の差が比 較的判然として扣り, 九州 20 昂, イスズナタネは発病少 く, 農林 17 号最む発病多く, ついで農林 14 号, ミチノ クナタネ, 福系 268-11--4 の順に多く, その他は中程 度であつた。

实験 4 . 実験 3 と全く同一方法にて栽培した艎接種区 （1区 1 坪 3 区制）について，同様に5 月 25 日調査を行 つた結果は第 9 䒾のようである.

第 9 表 菜種菌核病心刘する抵抗性の品種間差港

(1956. 5)

\begin{tabular}{|c|c|c|c|c|c|}
\hline \multirow{2}{*}{\multicolumn{2}{|c|}{ 供試品㮔 }} & & 害 & \multicolumn{2}{|c|}{$(\%)$} \\
\hline & & I & II & III & 平 均 \\
\hline $\begin{array}{l}1 \\
2 \\
3 \\
4 \\
5 \\
6 \\
7 \\
8 \\
9 \\
10 \\
11 \\
12\end{array}$ & 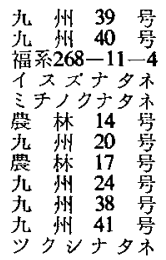 & $\begin{array}{rl}11.7 & 0 \\
0 \\
1.7 \\
13.3 \\
16.7 \\
6.7 \\
10.0 \\
8.3 \\
3.3 \\
1.7 \\
11.7 \\
1.7\end{array}$ & $\begin{array}{r}1.7 \\
3.3 \\
1.7 \\
21.7 \\
8.3 \\
11.7 \\
6.7 \\
21.7 \\
8.3 \\
0 \\
5.0 \\
6.7\end{array}$ & $\begin{array}{r}5.0 \\
10.0 \\
6.7 \\
21.7 \\
18.3 \\
20.0 \\
3.3 \\
23.3 \\
15.0 \\
0 \\
25.0 \\
5.0\end{array}$ & $\begin{array}{r}6.1 \\
4.4 \\
3.4 \\
18.9 \\
14.4 \\
12.8 \\
6.7 \\
17.8 \\
8.9 \\
0.6 \\
13.9 \\
4.5\end{array}$ \\
\hline
\end{tabular}

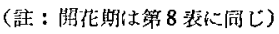

第9 表の結果をみるに接種区に比し発病は勿菕少かつ たが，その傾向は略々一致しているょうである、唯接種 区に比しイスズナタネの発病がかなり多からた。

\section{3. 総括}

以上 3 ケ年の奉験結果を総括すれば第 10 表のようで ある。 
更に発病程度の多少上り品種を大別す れば第 11 婊のようである。

大体第 11 㳖の如く洋別し得るが, 栽培 袈境，気象条件（こ」では 3 年間の気像 表は省略する）等がかなり影啷を及ばす よ5であり，この傾问は発病中位の品種 に和いて特に著しかつた。これらの事よ り侵入期期の差又は生熊種があるとすれ

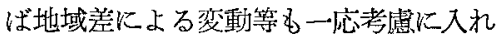
られるべきであるうと思われる，更に㕛 別に行つた案内接種実験の結果等からし てみてる，間場に拈ける発病抵抗は，品

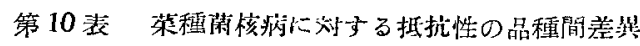
（被害指数（\%) 2 4区本均 1953.10１956.5)

\begin{tabular}{|c|c|c|c|c|c|c|c|c|c|c|}
\hline \multirow{2}{*}{ 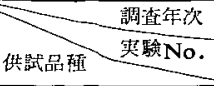 } & 1954 & \multicolumn{4}{|c|}{1955} & \multicolumn{4}{|c|}{1956} & \multirow{2}{*}{ 総平均 } \\
\hline & 1 & 1 & 2 & 3 & 4 & 1 & 2 & 3 & 4 & \\
\hline 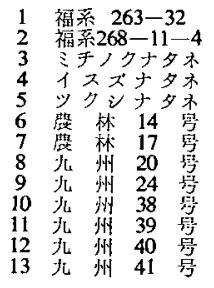 & $\begin{array}{r}13.1 \\
24.9 \\
31.3 \\
5.6\end{array}$ & $\begin{array}{l}14.9 \\
38.8 \\
\\
31.3 \\
38.9 \\
48.7 \\
11.1 \\
20.2 \\
28.5 \\
15.3\end{array}$ & $\begin{array}{r}3.3 \\
10.4 \\
2.9 \\
4.6 \\
7.5 \\
8.7 \\
2.0 \\
7.5 \\
7.8 \\
3.3\end{array}$ & $\begin{array}{r}5.4 \\
8.8 \\
26.2 \\
2.9 \\
11.3 \\
9.6 \\
10.8\end{array}$ & $\begin{array}{r}10.9 \\
10.9 \\
20.0 \\
5.0 \\
10.8 \\
7.5 \\
4.2\end{array}$ & $\begin{array}{l}35.1 \\
52.2 \\
29.1 \\
17.8 \\
36.9 \\
53.1 \\
14.2 \\
24.7 \\
21.6 \\
32.2 \\
41.3 \\
22.0\end{array}$ & $\begin{array}{r}5.1 \\
14.7 \\
7.8 \\
2.6 \\
9.4 \\
10.9 \\
7.6 \\
2.7 \\
2.7 \\
7.5 \\
5.8 \\
5.5\end{array}$ & $\begin{array}{r}17.1 \\
19.6 \\
7.9 \\
11.7 \\
22.5 \\
27.1 \\
6.7 \\
12.1 \\
11.3 \\
13.4 \\
10.4 \\
14.6\end{array}$ & $\begin{array}{r}3.4 \\
14.4 \\
18.9 \\
4.5 \\
12.8 \\
17.8 \\
6.7 \\
8.9 \\
0.6 \\
6.1 \\
4.4 \\
13.9\end{array}$ & $\begin{array}{r}34.7 \\
10.8 \\
21.5 \\
13.3 \\
11.3 \\
19.2 \\
27.1 \\
6.9 \\
12.3 \\
11.2 \\
11.7 \\
15.5 \\
14.0\end{array}$ \\
\hline $\mathrm{F}$ 娭定 |㟧程间 & $* *$ & $* *$ & $\begin{array}{l}* * \\
* *\end{array}$ & $* *$ & - & $* *$ & $*$ & $* *$ & $\begin{array}{l}* * \\
*\end{array}$ & \\
\hline 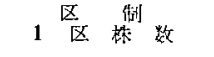 & $\begin{array}{r}3 \\
30\end{array}$ & $\begin{array}{r}3 \\
30\end{array}$ & $30^{3}$ & $\begin{array}{r}4 \\
12\end{array}$ & $\begin{array}{r}2 \\
12\end{array}$ & $\begin{array}{r}3 \\
30\end{array}$ & $\begin{array}{r}3 \\
30\end{array}$ & $\begin{array}{r}4 \\
12\end{array}$ & $\begin{array}{r}3 \\
12\end{array}$ & \\
\hline
\end{tabular}

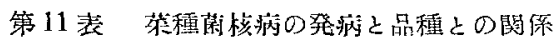

\begin{tabular}{|c|c|}
\hline 発病の多少 & 品 \\
\hline 発病の少、品转 & (1) 九 州 20 昂 \\
\hline 笞病中位の品程 & 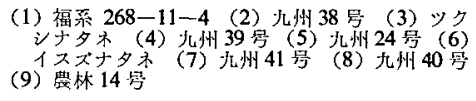 \\
\hline 楚疤の多い品稙 & 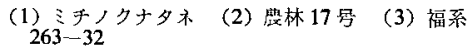 \\
\hline $\begin{array}{l}\text { (䛠) 被害指数 } \\
\text { 多 }(30 \%\end{array}$ & 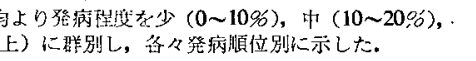 \\
\hline
\end{tabular}

種自体の抵抗性のみならず，品種の特性或は環境条件に 基く被害回避の場面もかなり関与しているものと考えら れる.この固場に拈ける抵抗性品種間差異の発現は何故 に括こるかの機桪については，目下追究中であるので後 日報告する予定である.尚本病の発生と開花期との関係 については，一般に早生種に発病が多いかの如くいわれ ているが本実験では一定の傾向觉何うことが出来なから だ

\section{4. 摘 要}

1.本研究は 1953 年より 1955 年にかけ, 莱種菌核病に 対する担抗性の品種間差異について行つたものである.

2. その結果九州 20 号は比較的発病少く, その他に若 干の発病の稍々少いと思われる品種を認めたが，これら は品種当体による差のみならず莱種の性状や環境その他 の諸条件に基く被慧回避場面るかなり関与しているょう に思われる。

3. 本病の発生と開花期との関係は，正の相関を見出す 事は因難であつた.

\section{参考文 献}

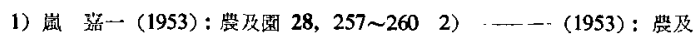
图 28, 371 374 3) -

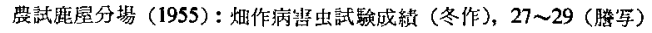

14. 菜種苗根鹰病に関する研究 第 3 報 水銀乳戍の濃度と薬害及び效果との関係 宇都敏夫・

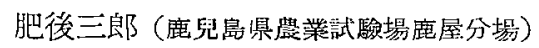

菜種苗根腐病の防除に, 水銀孚剂の $800 \sim 1,000$ 倍液 （酶酸フェニール水銀 $5 \%$, 有機態水銀 $3 \%$ ) を, 播糧後 30 日迄の闒に, 2 3 回灌洼すると, 極めて䫓著な效果 を示じたが，この濃度では薬㫪を生じて赛用的でなから たので, 更に濃度について䄼傠を行つた. 其の結果, 略 々実用的な濃度と防除方法を梌知し得たので，その概要 を報告する。

\section{1. 浸漬法による菌堂の生死}

子女殺菌效果の劣る澧度を知る目的で，ミクロデン乳 剂（鹿化学製品, 酶酸つェニール水銀 $5 \%$, 有機態水銀 3\%)の 400 倍液から，200 倍きざみに 2,000 倍液迄の 濃度としたものに, ·苗根腐病菌 (Pythium $\mathrm{sp}$.)の菌讜を
5〜10 分間浸漬し，その生死によつて效果を検討した。

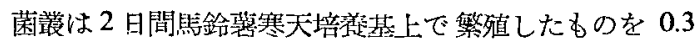
$\mathrm{cm}$ に切断して用い，漫清挠山蒸溜水にて上く洗涤し， 再び新らしい培蕴基に移㥀して, 菌誮の発育の有無に上 うて, その生死を判断した.

此の結果は第 1 表の如くであつて，5分で 1,000 倍迄 は有效であって，1,200倍よりは效果はなく文 10 分では 1,400 倍をで効果がある.この試験は菌灙を 5〜10 分間 浸漬した結果で, 野外に於ては土境の状態, 及び接触时 間等で相違するるのと思われるのであるが，1,000 倍以 上の濃度でも怰果があるように推察される.

\section{2. 、播種前に処理する場合の僲度}

